\title{
Article \\ Synthesis and Characterizations of Barium Zirconate-Alkali Carbonate Composite Electrolytes for Intermediate Temperature Fuel Cells
}

\author{
Gilles Taillades ${ }^{1, *}$, Ismahan Hachemi ${ }^{1}$, Paul Pers ${ }^{1}$, Julian Dailly ${ }^{2}$ and Mathieu Marrony ${ }^{2}$ \\ 1 Institut Charles Gerhardt Montpellier, Université de Montpellier, Place E. Bataillon, 34095 Montpellier, France; \\ ismahan.hachemi@etu.umontpellier.fr (I.H.); paul.pers@umontpellier.fr (P.P.) \\ 2 European Institute for Energy Research (EIFER), Emmy-Noether-Str. 11, 76131 Karlsruhe, Germany; \\ Julian.Dailly@eifer.uni-karlsruhe.de (J.D.); Mathieu.Marrony@eifer.uni-karlsruhe.de (M.M.) \\ * Correspondence: gilles.taillades@umontpellier.fr
}

check for updates

Citation: Taillades, G.; Hachemi, I.; Pers, P.; Dailly, J.; Marrony, M. Synthesis and Characterizations of Barium Zirconate-Alkali Carbonate Composite Electrolytes for Intermediate Temperature Fuel Cells. J. Compos. Sci. 2021, 5, 183. https:// doi.org/10.3390/jcs5070183

Academic Editors: Patrizia Bocchetta and Domenico Frattini

Received: 26 May 2021

Accepted: 6 July 2021

Published: 10 July 2021

Publisher's Note: MDPI stays neutral with regard to jurisdictional claims in published maps and institutional affiliations.

Copyright: (c) 2021 by the authors. Licensee MDPI, Basel, Switzerland. This article is an open access article distributed under the terms and conditions of the Creative Commons Attribution (CC BY) license (https:// creativecommons.org/licenses/by/ $4.0 /)$.

\begin{abstract}
Composite ionic conductors for intermediate temperature fuel cells (ITFC) were produced by a combination of yttrium-substituted barium zirconate $\left(\mathrm{BaZr}_{0.9} \mathrm{Y}_{0.1} \mathrm{O}_{2.95}, \mathrm{BZY}\right)$ and eutectic compositions of alkali carbonates $\left(\mathrm{Li}_{2} \mathrm{CO}_{3}, \mathrm{Na}_{2} \mathrm{CO}_{3}\right.$, and $\mathrm{K}_{2} \mathrm{CO}_{3}$, abbreviated $\left.\mathrm{L}, \mathrm{N}, \mathrm{K}\right)$. These materials were characterized by $\mathrm{X}$-ray diffraction, scanning electron microscopy, and impedance spectroscopy. The combination of BZY with alkali metal carbonate promotes the densification and enhances the ionic conductivity, which reaches $87 \mathrm{mS} \cdot \mathrm{cm}^{-1}$ at $400{ }^{\circ} \mathrm{C}$ for the BZY-LNK40 composite. In addition, the increase of the conductivity as a function of hydrogen partial pressure suggests that protons are the main charge carriers. The results are interpreted in terms of the transfer of protons from the ceramic component to the carbonate phase in the interfacial region.
\end{abstract}

Keywords: fuel cell electrolyte; composite electrolyte; barium zirconate; molten carbonates; conductivity

\section{Introduction}

The development of electrochemical devices toward clean energy generation has been intensified in the last years. In this context, fuel cells, and especially solid oxide fuel cells (SOFC), have received much attention. The working temperature of SOFCs is typically in the order of $800-1000{ }^{\circ} \mathrm{C}$ due to the high activation energy required by the materials to attain suitable levels of conductivity values and catalytic activity. Lower operation temperatures would decrease the rate of chemical and mechanical degradations of SOFC components, thus decreasing operation and maintenance costs. Additionally, fabrication cost would lower as well, since low-cost components could replace the high-temperatureresistant materials commonly used. For instance, expensive ceramic-based interconnects, which are currently required to avoid undergo chemical interaction with the electrodes at high temperatures, could be replaced by cost-efficient metallic-based interconnects that can be safely used below $700{ }^{\circ} \mathrm{C}$. Therefore, to develop market-competitive Solid Oxide Fuel Cells (SOFC), considerable research efforts are ongoing to decrease the cell operation temperature in order to reduce the manufacturing and operating costs and increase the durability $[1,2]$. Three main research strategies have been developed to decrease the operation temperature of SOFC to the low-temperature range $\left(400-600^{\circ} \mathrm{C}\right)$ : reduce the electrolyte thickness, improve the conduction properties of existing materials, or find new materials with higher ionic conductivities. Among the new electrolyte materials investigated, two phase ceria-cerium carbonate-based nanocomposites have been extensively explored in recent years [3-8].

The conduction mechanism in these composites is a subject of controversy. In the literature, the ionic conductivity of ceria-alkaline carbonate composites is currently explained by a mechanism involving protons (or hydrogen carbonates) along the ceramic-salt 
interface $[9,10]$. The complexity of these systems is linked to the presence of numerous charge carriers including alkali metal, carbonate and oxide ions, and protons. In addition, molten carbonates interact with the gas phase, and hydrogen carbonate or hydroxide ions can form.

Surprisingly, very limited work has been carried out on composites of a protonconducting ceramic and alkali metal carbonates. Huang et al. [11,12] have conducted two studies on the ionic conduction in $\mathrm{BaZr}_{0.8} \mathrm{Y}_{0.2} \mathrm{O}_{3-\mathrm{d}}-\mathrm{LiKCO}_{3}$ and $\mathrm{BaZr}_{0.8} \mathrm{Y}_{0.2} \mathrm{O}_{3-\mathrm{d}}-\mathrm{LiNaCO}_{3}$ composites. These composites were prepared by infiltration of the molten carbonate phase into $\mathrm{BaZr}_{0.8} \mathrm{Y}_{0.2} \mathrm{O}_{3-\mathrm{d}}$ that was previously sintered at high temperature $\left(1500{ }^{\circ} \mathrm{C}\right)$, and the high conductivity of these composites was attributed to synergetic proton conduction between $\mathrm{BaZr}_{0.8} \mathrm{Y}_{0.2} \mathrm{O}_{3-\mathrm{d}}$ and the carbonate phases. Using $\mathrm{Ni}$ as an anode, a single cell was constructed with BCZY-LNC as electrolyte and lithiated nickel oxide as cathode, providing a maximum power density of $957 \mathrm{~mW} \mathrm{~cm}{ }^{-2}$ at $600{ }^{\circ} \mathrm{C}$ [12]. As hydrogen and oxygen were used as the fuel and the oxidant, this work supports the existence of a proton conductivity.

To the best of our knowledge, composites based on doped barium zirconate and the ternary eutectic mixture of $\mathrm{Li}_{2} \mathrm{CO}_{3}, \mathrm{Na}_{2} \mathrm{CO}_{3}$, and $\mathrm{K}_{2} \mathrm{CO}_{3}$ have not been investigated previously, and we describe here a systematic study of ionic conduction in the $\mathrm{BaZr}_{0.9} \mathrm{Y}_{0.1} \mathrm{O}_{2.95} / \mathrm{Li}_{2} \mathrm{CO}_{3}-\mathrm{Na}_{2} \mathrm{CO}_{3}-\mathrm{K}_{2} \mathrm{CO}_{3}$ system.

\section{Materials and Methods}

The ethylene diamine tetra-acetic acid (EDTA)-assisted glycine-nitrate combustion Process (GNP) was used to prepare $\mathrm{BaZr}_{0.9} \mathrm{Y}_{0.1} \mathrm{O}_{3-\mathrm{d}}$ (BZY) nano-powders using metal nitrates $\mathrm{Ba}\left(\mathrm{NO}_{3}\right)_{2}, \mathrm{ZrO}\left(\mathrm{NO}_{3}\right)_{2} \cdot 6 \mathrm{H}_{2} \mathrm{O}$ and $\mathrm{Y}\left(\mathrm{NO}_{3}\right)_{3} \cdot 6 \mathrm{H}_{2} \mathrm{O}$ (Aldrich, $\left.99.9 \%\right)$ as starting materials. The appropriate molar ratio of metal nitrates is dissolved in deionized water under heating. Then, glycine and EDTA are added to the nitrate solution. The molar ratio of glycine and EDTA to the total metal cations were set to 1.5:1 and 1:1 respectively. Then, the appropriate volume of $\mathrm{NH}_{3}$ was slowly dripped into this solution until a clear solution of $\mathrm{pH}$ 6-7 was obtained. The beaker was placed to a heating plate at $80^{\circ} \mathrm{C}$, and upon evaporation of water, a yellow gel gradually formed. At this point, the beaker was placed in an oven pre-heated at $600^{\circ} \mathrm{C}$. The combustion reaction takes place within a few minutes, forming the as-synthesized powders, which were subsequently calcined at $900{ }^{\circ} \mathrm{C}$ for $10 \mathrm{~h}$ to obtain the powder with the desired composition.

Three carbonate systems corresponding to eutectic compositions were selected for this study: $62 \mathrm{~mol} \% \mathrm{Li}_{2} \mathrm{CO}_{3}-38 \mathrm{~mol} \% \mathrm{~K}_{2} \mathrm{CO}_{3}$ (LK), $52 \mathrm{~mol} \% \mathrm{Li}_{2} \mathrm{CO}_{3}-48 \mathrm{~mol} \% \mathrm{Na}_{2} \mathrm{CO}_{3}$ (LN), and $43.5 \mathrm{~mol} \% \mathrm{Li}_{2} \mathrm{CO}_{3}-25 \mathrm{~mol} \% \mathrm{~K}_{2} \mathrm{CO}_{3}-31.5 \mathrm{~mol} \% \mathrm{Na}_{2} \mathrm{CO}_{3}(\mathrm{LKN})$. The melting temperatures of the carbonate mixtures used are given in Table 1.

Table 1. Composition and melting temperature of binary and ternary alkali carbonate eutectics.

\begin{tabular}{ccccc}
\hline \multirow{2}{*}{ Systems } & \multicolumn{3}{c}{ Composition mol\%. } & Melting Temperature ${ }^{\circ} \mathbf{C}$. \\
\cline { 2 - 5 } & $\mathbf{L i}_{2} \mathrm{CO}_{3}$ & $\mathbf{K}_{2} \mathrm{CO}_{3}$ & $\mathbf{N a}_{2} \mathrm{CO}_{3}$ & \\
\hline $\mathrm{Li}_{2} \mathrm{CO}_{3}-\mathrm{K}_{2} \mathrm{CO}_{3}$ & 62 & 38 & - & 488 \\
$\mathrm{Li}_{2} \mathrm{CO}_{3}-\mathrm{Na}_{2} \mathrm{CO}_{3}$ & 52 & - & 48 & 501 \\
$\mathrm{Li}_{2} \mathrm{CO}_{3}-\mathrm{K}_{2} \mathrm{CO}_{3}-\mathrm{Na}_{2} \mathrm{CO}_{3}$ & 43.5 & 25 & 31.5 & 397 \\
\hline
\end{tabular}

The carbonates were co-melted and mixed in an alumina crucible at $520{ }^{\circ} \mathrm{C}$ for $40 \mathrm{~min}$ and then cooled, collected, and ground in a mortar. Then, the as-prepared mixed carbonates and $\mathrm{BZY}$ powder were mixed in the weight ratio $\mathrm{BZY} /$ carbonates $70 / 30 \mathrm{wt} \%$ (denoted BZY-LN30, BZY-LK30, BZY-LKN30), ground again, and pressed at $30 \mathrm{MPa}$ into pellets with a diameter of $13 \mathrm{~mm}$ and a thickness of $1 \mathrm{~mm}$. Then, the pellets were sintered at $650{ }^{\circ} \mathrm{C}$ for $1 \mathrm{~h}$ in air with heating and cooling rates of $5^{\circ} \mathrm{C} / \mathrm{min}$. In case of the BZY-LKN system, the composites 80/20 wt \% (BZY-LKN20) and 60/40 wt \% (BZY-LKN40) were also prepared in order to investigate the influence of the proportion of oxide/carbonate on the conductivity. 
The phase identification of synthesized powders and prepared composites was determined by $\mathrm{X}$-ray diffraction using a Seifert diffractometer with $\mathrm{CuK}_{\alpha}$ radiation. XRD patterns were recorded over an angular range of $2 \theta=20-80^{\circ}$ with a step size of $0.03^{\circ}$. The microstructure of the materials was characterized by Scanning Electron Microscopy (SEM, FEI Quanta 200). The electrical conductivity of the electrolytes was determined by impedance spectroscopy (from $1 \mathrm{~Hz}$ to $100 \mathrm{kHz}$ with an AC voltage amplitude of $10 \mathrm{mV}$ ) using a potentiostat/galvanostat/EIS instrument (Biologic SP150). After mechanically polishing of the surface of the pellets, platinum paste (Heraeus, Buford, GA, USA) was coated onto the two sides of the composite electrolytes as electrodes. The platinum ink was dried at $150^{\circ} \mathrm{C}$ for $30 \mathrm{~min}$.

\section{Results and Discussion}

\subsection{X-ray Diffraction and Composite Microstructure}

The XRD diffraction patterns of the sintered BZY and BZY-carbonate composites are presented in Figure 1. BZY synthesized by the EDTA-assisted GNP shows a wellcrystallized cubic perovskite structure with a lattice parameter a $=4.213(3) \AA$, which is in agreement with the data reported in the literature [13]. Some small peaks related to barium carbonate and yttrium oxyde are still present after calcination at $900{ }^{\circ} \mathrm{C}$ in air.

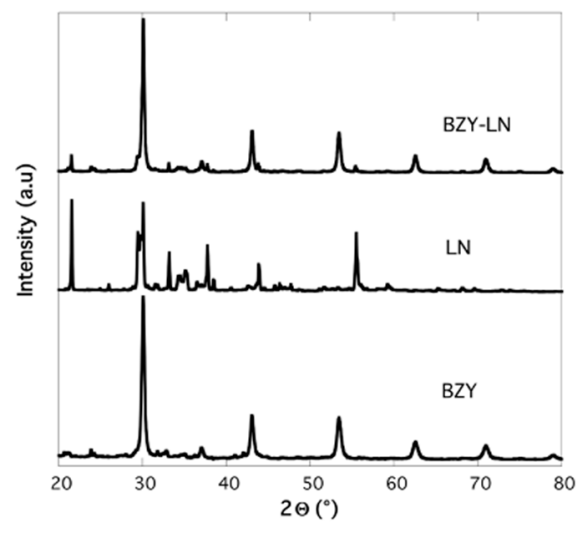

(a)

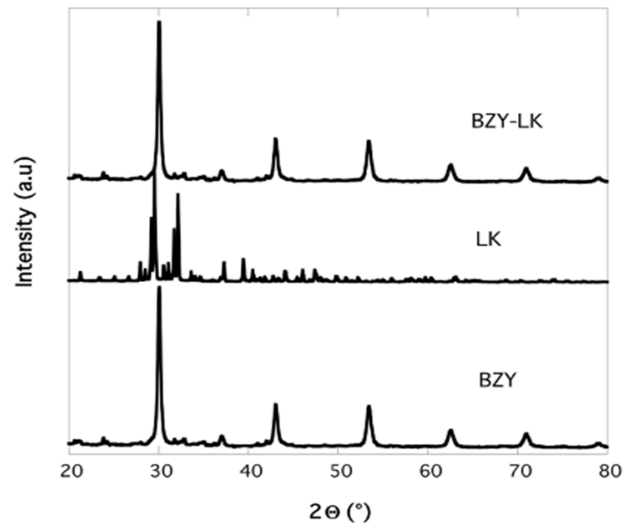

(b)

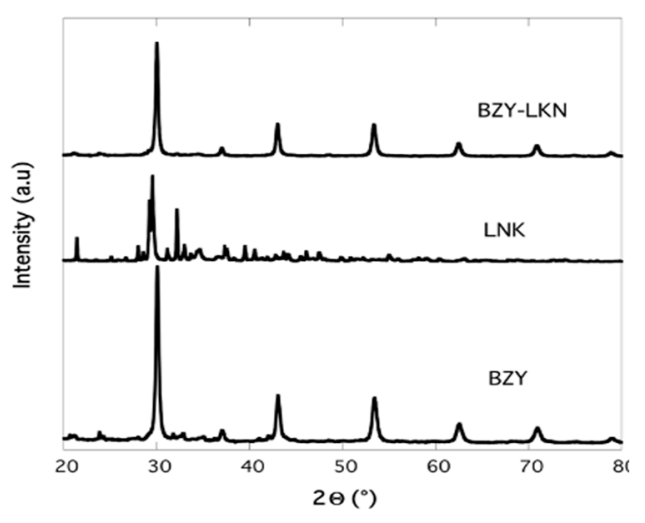

(c)

Figure 1. XRD patterns of BZY, alkali carbonates, and BZY-alkali carbonate composites. (a) BZY-LN; (b) BZY-LK; (c) BZY-LKN.

For all the composite compositions, the predominant phase is BZY, and the low intensity of the peaks given by the carbonates suggests them to be mostly present as amorphous phases. However, peaks for ( $\mathrm{LiNa})_{2} \mathrm{CO}_{3}$ (JCPDS\#00-034-1193), $\mathrm{Li}_{2} \mathrm{CO}_{3}$ (JCPDS\# 01-080-1307), and $\mathrm{Na}_{2} \mathrm{CO}_{3}$ (JCPDS\#00-019-1130) are identified and are consistent with similar observations $[7,8,12]$. In this way, the XRD results indicate that no chemical reaction 
has occurred between BZY and the three alkali carbonates. The stability of the composites was also checked by XRD after a heat treatment at $600{ }^{\circ} \mathrm{C}$ during $24 \mathrm{~h}$ under reducing atmosphere: no reactivity or structural transformation was observed. SEM micrographs of fractured surfaces of the BZY pellet sintered at $1450{ }^{\circ} \mathrm{C}$, BZY-LK, BZY-LN, and BZY-LKN composites are shown in Figure 2.

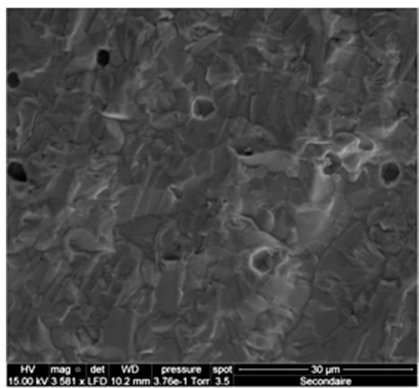

(a)

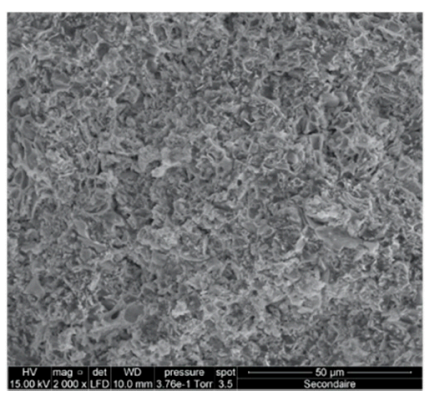

(b)

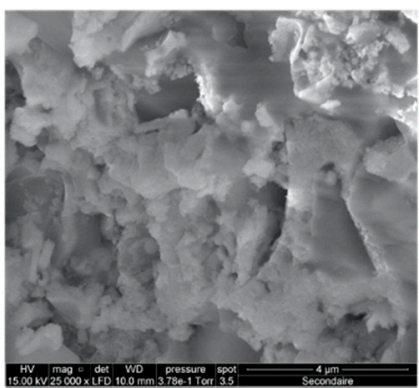

(c)

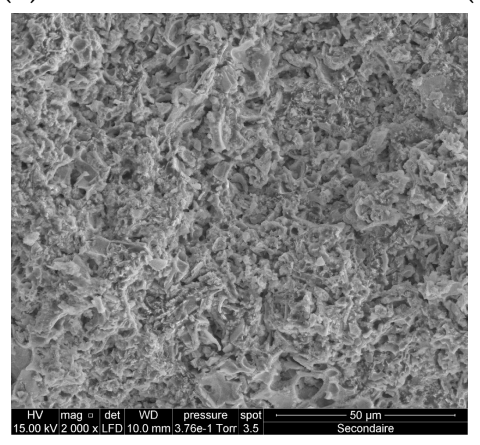

(d)

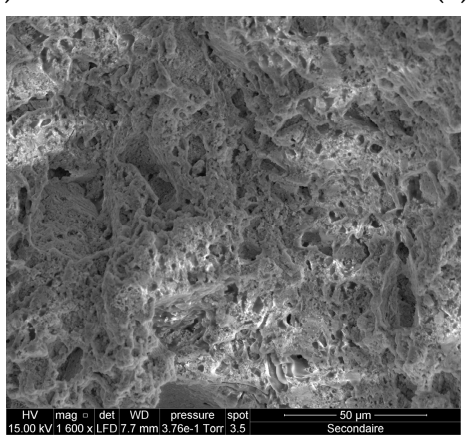

(e)

Figure 2. Representative SEM images of (a) BZY (b,c) BZY-LK, (d) BZY-LN, and (e) BZY-LKN composites.

Figure 2a shows the typical cross-sectional SEM micrograph of the reference BZY pellet sintered at $1450{ }^{\circ} \mathrm{C}$; the sample exhibits a quite dense microstructure with a relative density higher than $93 \%$. As seen from Figure $2 b$, the BZY-LK composite pellet shows a relatively high density without any open pores, even though the sintering temperature is only $650{ }^{\circ} \mathrm{C}$. A higher magnification image (Figure 2c) shows that the ceramic grains appear lightly bound together. SEM micrographs of the two other compositions are similar (Figure 2d,e). As the carbonate mixture melts during sintering, it can be deduced that it coated the ceramic particles, served as a glue, and provides the mechanical stability of the samples. It is important to note that pellets prepared with BZY powder only and heat-treated under the same conditions (at $650{ }^{\circ} \mathrm{C}$ for $1 \mathrm{~h}$ ) have no mechanical strength. These observations are similar to those reported for ceria- [8] or BZY-based carbonate composites [11] prepared by mechanical mixing of the two phases. However, the composites elaborated by the infiltration route show clearly different microstructures with separated ceramic and carbonate structures wherein the carbonate resides in the pores of the ceramic skeleton $[7,14-16]$.

\subsection{Electrical Conductivity of BZY-Carbonate Composite Electrolytes}

The conductivities of yttrium-substituted barium zirconate-alkali metal carbonate composite electrolytes were determined using impedance spectroscopy. Figure 3 shows the impedance spectra of BZY-LK30 at 350 and $400{ }^{\circ} \mathrm{C}$ (Figure 3a) and at $500{ }^{\circ} \mathrm{C}$ with various signal amplitudes (Figure $3 b$ ). As shown in Figure 3b, the low-frequency contribution decreases with increasing amplitude, which is characteristic of electrode processes [16]. The high-frequency contribution remains independent of the amplitudes and can be attributed to the ionic conductivity of the composite. At lower temperature, the first semi- 
circle of the spectrum in each case can be identified as the ohmic contribution (Figure 3a), while at high temperature (Figure 3b), the first semi-circle disappears, and the resistance of the electrolyte is taken at the intersection of the curve with the x-axis.

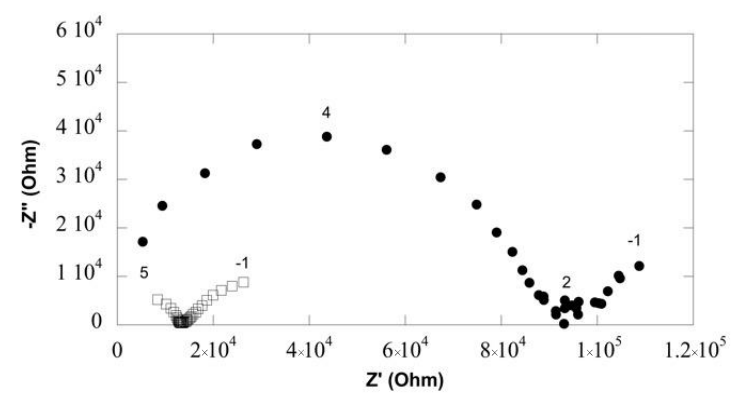

(a)

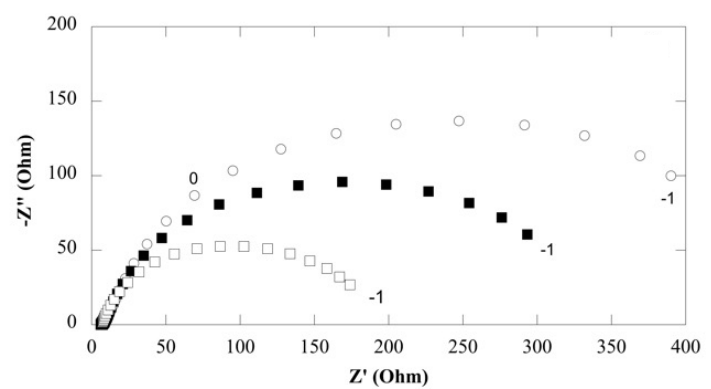

(b)

Figure 3. Impedance spectra of BZY-LK30 composites measured under air at (a) $350{ }^{\circ} \mathrm{C}(\bullet)$ and $400{ }^{\circ} \mathrm{C}(\square)$ and (b) at $500{ }^{\circ} \mathrm{C}$ under different amplitudes: $10 \mathrm{mV}(\bigcirc), 100 \mathrm{mV}(\mathbf{\square})$, and $200 \mathrm{mV}(\square)$. The numbers correspond to the frequency logarithm.

Figure 4 shows the Arrhenius plot for pure BZY and for the three composite electrolytes in air. While BZY shows a relatively linear dependence in the temperature range investigated, a sharp conductivity jump is observed a few degrees before the melting temperature of the carbonate phases for the three composites.

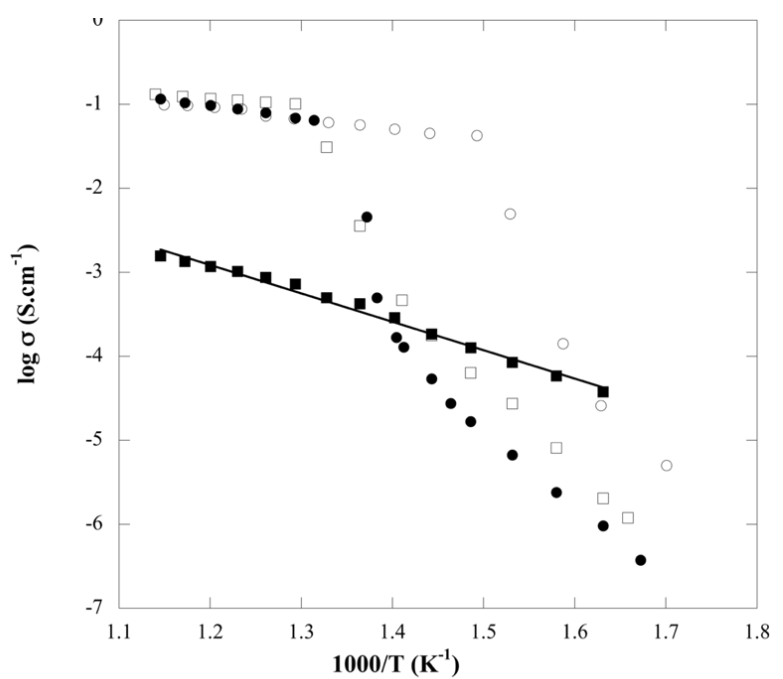

Figure 4. Arrhenius plots of the conductivity of BZY-LN30 (口), BZY-LK30 (•), BZY-LKN30 (○), and BZY (ם) under dry air.

In this way, the Arrhenius diagrams of the composites can be separated into three domains. At low temperature, the conductivities of the composites are lower than that of 
$\mathrm{BZY}$ and characterized by activation energies higher than $1 \mathrm{eV}$. This can be explained by a partial blocking effect of the conduction paths by solid carbonates in this temperature range. Thus, it appears that at low temperature, the ionic conductivity is principally controlled by the BZY phase. This hypothesis is confirmed by the increase in conductivity at low temperature when the BZY content increases (Figure 5).

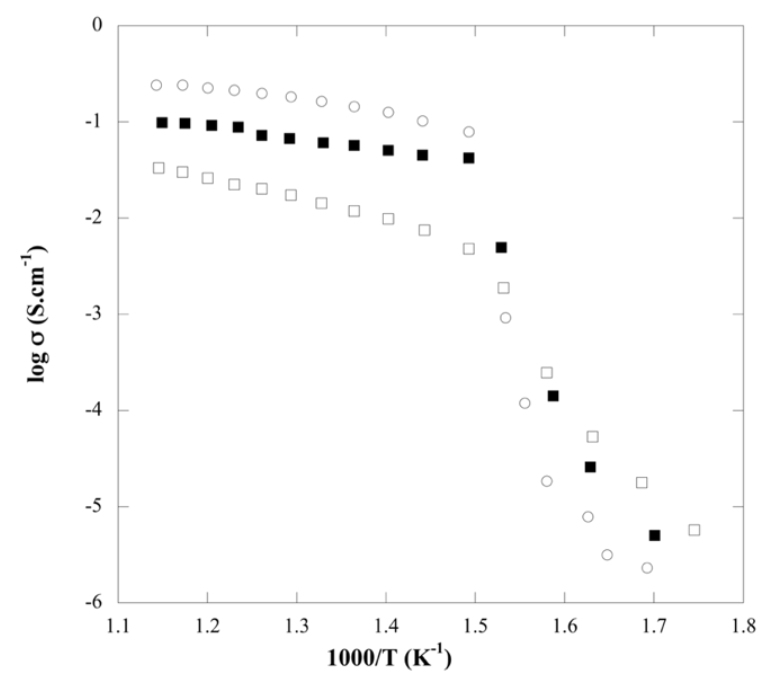

Figure 5. Arrhenius plot of the conductivity of BZY-LKN composites under air $(\bigcirc$ : BZY-LKN40, 口: BZY-LKN30, $\square$ : BZY-LKN20).

At intermediate temperatures, just above the carbonate melting temperature, the conductivity increases drastically. In this range, another conductivity pathway must be considered. Zhu et al. [17,18] have proposed an interfacial conduction mechanism to explain the ionic conduction behavior of ceria-based composites. The rise in conductivity is attributed to a high concentration of defects at the interfaces between the ceria particles surface and partially molten carbonates. One hypothesis is that this space charge zone acts as a superionic pathway as well in case of proton conducting ceramic-carbonate composites.

At temperatures higher than the melting point of the carbonate phases, the conductivities of the composites are two orders of magnitude higher than that of BZY and reach 117, 97 , and $86 \mathrm{mS} \cdot \mathrm{cm}^{-1}$ at $550^{\circ} \mathrm{C}$ for BZY-LN, BZY-LK, and BZY-LKN, respectively. In this high-temperature domain, the activation energies obtained are lower than those of pure BZY and close to those of pure molten carbonates [6], as shown in Table 2.

Table 2. Calculated activation energies and conductivities for BZY-alkali carbonate composites. Ea $\mathrm{HT}$ corresponds to the activation energies in the high-temperature domain.

\begin{tabular}{cccccc}
\hline & BZY-LN30 & BZY-LK30 & BZY-LKN30 & BZY-LKN20 & BZY-LKN40 \\
\hline Atmosphere & air $/ \mathrm{H}_{2}$ & air $/ \mathrm{H}_{2}$ & Air $/ \mathrm{H}_{2}$ & air & air \\
Ea $\mathrm{HT}(\mathrm{eV})$ & $0.15 / 0.18$ & $0.30 / 0.34$ & $0.22 / 0.25$ & 0.36 & 0.30 \\
$\sigma_{500}{ }^{\circ} \mathrm{C}\left(\mathrm{mS} \cdot \mathrm{cm}^{-1}\right)$ & $100 / 113$ & $71 / 102$ & $69 / 101$ & 17 & 192 \\
$\sigma_{400}{ }^{\circ} \mathrm{C}\left(\mathrm{mS} \cdot \mathrm{cm}^{-1}\right)$ & $6.3 \times 10^{-2} / 8.1 \times 10^{-2}$ & $1.6 \times 10^{-2} / 3 \times 10^{-2}$ & $38 / 47$ & 5 & 89 \\
\hline
\end{tabular}

These results are consistent with the literature showing higher conductivity for the LN than the LK system [6] and activation energies in the range of $0.15-0.3 \mathrm{eV}[8,10]$. So, it is worth noting that the conductivity depends on the composite microstructure and on the carbonate loading. As shown in Figure 5, the conductivity of the BZY-LKN system increases with the carbonate loading in the high-temperature range. Thus, study of the three parameters-conductivity, evolution of the conductivity as a function of the nature 
of the carbonate, and carbonate loading-lead to the conclusion that the conductivity is dominated by the carbonate phase in the high-temperature domain.

Table 3 compares the results obtained in this work with the two published studies on BZY-MC composites. Li et al. [11] and Xiong et al. [10] have obtained $160 \mathrm{mS} \cdot \mathrm{cm}^{-1}$ and $182 \mathrm{mS} \cdot \mathrm{cm}^{-1}$ respectively at $500{ }^{\circ} \mathrm{C}$ under air for the BZY-LK50 composite prepared by infiltration of a BZY porous backbone. As expected, the conductivity obtained in this work for the BZY-LK30 $\left(71 \mathrm{mS} \cdot \mathrm{cm}^{-1}\right)$ is lower, as the conductivity decreases with a lower carbonate loading. Nevertheless, the BZY-LKN40 shows a higher conductivity at $500{ }^{\circ} \mathrm{C}$ $\left(192 \mathrm{~S} . c m^{-1}\right)$, and the conductivity of this composite remains even higher than $100 \mathrm{mS} \cdot \mathrm{cm}^{-1}$ until $400^{\circ} \mathrm{C}$. In any case, the composite conductivities are two orders of magnitude higher than BZY conductivity.

Table 3. Conductivities of BZY and BZY-MC composites at $500{ }^{\circ} \mathrm{C}$ under air.

\begin{tabular}{|c|c|c|c|c|c|}
\hline & BZY & BZY-LK50 & BZY-LK50 & BZY-LK30 & BZY-LKN40 \\
\hline $\begin{array}{c}\sigma_{500}{ }^{\circ} \mathrm{C} \\
\left(\mathrm{mS} \cdot \mathrm{cm}^{-1}\right) \\
\text { Reference }\end{array}$ & $\begin{array}{c}0.8 \\
\text { this work }\end{array}$ & $\begin{array}{l}182 \\
{[10]}\end{array}$ & $\begin{array}{l}160 \\
{[11]}\end{array}$ & $\begin{array}{c}69 \\
\text { this work }\end{array}$ & $\begin{array}{c}192 \\
\text { this work }\end{array}$ \\
\hline
\end{tabular}

In order to better understand the conduction mechanism, the conductivities of the three composites BZY-LK30, BZY-LN30, and BZY-LKN30 were measured in a reducing atmosphere. As shown in Figure 6, under 5\% hydrogen in argon, the BZY-LK30 composite electrolyte shows a similar conductivity behavior to that observed in air with a sharp conductivity jump near the eutectic melting temperature.

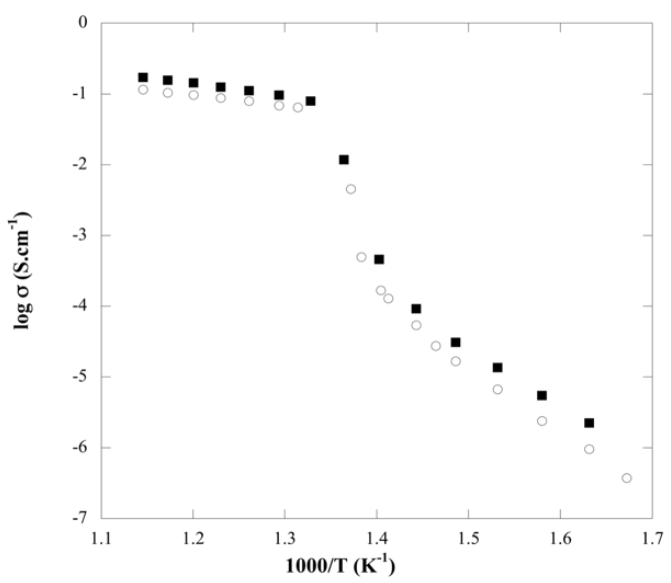

Figure 6. Arrhenius plot of the conductivity of BZY-LK30 composites under air $(\bigcirc)$ and hydrogen

However, the conductivity in a reducing atmosphere is higher than the conductivity in air over the whole temperature range (Figure 6) and increases as a function of the hydrogen partial pressure (Figure 7). The BZY-LN30 and BZY-LKN30 composites show the same behavior, the conductivity values at 400 and $500{ }^{\circ} \mathrm{C}$ are given in Table 2 . The higher conductivity in $\mathrm{H}_{2}$-containing atmospheres indicates that the conduction mechanism involves protonic species in both the oxide and carbonate phases.

It is well established [17] that the protonic defect formation in protonic conducting ceramics involves the creation of electronic defects as compensating charges as described in reaction 1.

$$
\frac{1}{2} \mathrm{H}_{2}+\mathrm{O}_{\mathrm{O}}^{\mathrm{x}} \rightarrow \mathrm{OH}_{\mathrm{O}}^{*}+\mathrm{e}^{\prime}
$$

It is important to underline that the electronic defects produced from the oxide cannot be transferred to the carbonate phase, which is electronically insulating. Experimentally, an open circuit voltage higher than $1 \mathrm{~V}$ has been obtained on a Pt/BZY-LK30/Pt cell under fuel cell operating conditions at $500{ }^{\circ} \mathrm{C}$, confirming a negligeable electronic conductivity. 


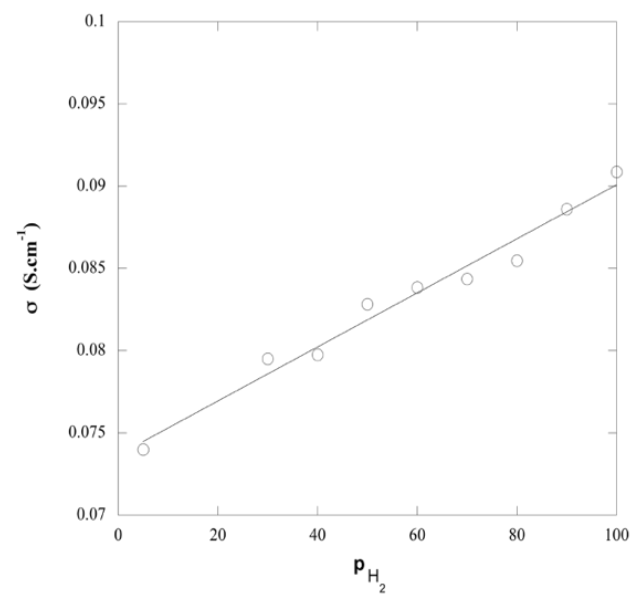

Figure 7. Conductivity of BZY-LK30 as a function of $\mathrm{p}_{\mathrm{H} 2}$ at $500{ }^{\circ} \mathrm{C}$.

This feature clearly constitutes an advantage of the composite in comparison with the single ceramic phase electrolytes.

However, and according to the numerous papers published on doped ceria-alkali carbonate composites, the transport in the carbonate phase under reducing atmosphere is mainly due to hydrogen carbonate ions $\left(\mathrm{HCO}_{3}^{-}\right)$in the intermediate and high-temperature domains. The formation of these $\mathrm{HCO}_{3}^{-}$species in BZY-alkali carbonate composites can be explained by proton transfer between the two phases in the interfacial region. The defect reaction associated with this transfer can be expressed by:

$$
\mathrm{OH}_{\mathrm{O}}^{*}+\left(\mathrm{CO}_{3}\right)_{\mathrm{CO}_{3}}^{\mathrm{x}}=\mathrm{O}_{\mathrm{O}}^{\mathrm{x}}+\left(\mathrm{HCO}_{3}\right)_{\mathrm{CO}_{3}}^{*} .
$$

The simultaneous proton conduction in the oxide phase (reaction 1), the extensive proton transfer along the interface (reaction 2), and consequently the proton conduction by $\mathrm{HCO}_{3}^{-}$. species in the carbonate phase lead to the increase of the conductivity with hydrogen partial pressure.

\section{Conclusions}

It was shown that dense composite pellets of BZY-LN, BZY-LK, and BZY-LKN composites with desired mechanical properties can be prepared at $650{ }^{\circ} \mathrm{C}$, highlighting the promotion of the densification by the carbonates. Arrhenius conductivity plots showed a discontinuity between a low-temperature region where the conductivity is controlled by the BZY phase and the high-temperature region where the conductivity is dominated by the carbonate phases. The composites exposed to $\mathrm{H}_{2}$-containing atmosphere exhibited higher conductivity than those measured under air. This dependence on hydrogen partial pressure suggests that proton conduction takes place in the whole temperature range with proton transfer from the oxide phase to the carbonate phase. More important, the BZY-LKN40 composite shows conductivity higher than $87 \mathrm{mS} \cdot \mathrm{cm}^{-1}$ at $400{ }^{\circ} \mathrm{C}$ and appears to be an excellent electrolyte candidate for the development of low-temperature proton conducting ceramic cells.

Author Contributions: G.T.: conceptualization, methodology, formal analysis, investigation, writing original draft, writing — review and editing. P.P. and I.H. formal analysis, investigation. J.D.: supervision, formal analysis, investigation, writing - review and editing. M.M.: formal analysis, project administration, resources. All authors have read and agreed to the published version of the manuscript.

Funding: This research received no external funding.

Conflicts of Interest: The authors declare no conflict of interest. 


\section{References}

1. Shi, H.; Su, C.; Ran, R.; Cao, J.; Shao, Z. Electrolyte materials for intermediate-temperature solid oxide fuel cells. Prog. Nat. Sci. Mater. Int. 2020, 30, 764-774. [CrossRef]

2. Gao, Z.; Mogni, L.V.; Miller, E.C.; Railsback, J.G.; Barnett, S. A perspective on low-temperature solid oxide fuel cells. Energy Environ. Sci. 2016, 9, 1602-1644. [CrossRef]

3. Fan, L.; Wang, C.; Chen, M.; Zhu, B. Recent development of ceria-based (nano)composite materials for low temperature ceramic fuel cells and electrolyte-free fuel cells. J. Power Sources 2013, 234, 154-174. [CrossRef]

4. Khan, I.; Asghar, M.I.; Lund, P.D. High conductive ( $\mathrm{LiNaK})_{2} \mathrm{CO}_{3} \mathrm{Ce}_{0.85} \mathrm{Sm}_{0.15} \mathrm{O}_{2}$ electrolyte compositions for IT-SOFC applications. Int. J. Hydrogen Energy 2017, 42, 20904-20909. [CrossRef]

5. Zhu, B.; Albinsson, I.; Anderson, C.; Borsand, K.; Nilsson, M.; Mellander, B. Electrolysis studies based on ceria-based composites. Electrochem. Commun. 2006, 8, 495-498. [CrossRef]

6. Patricio, S.G.; Papaioannou, E.; Zhang, G.; Metcalfe, I.S.; Marques, F.M.B. High performance composite $\mathrm{CO}_{2}$ separation membranes. J. Membr. Sci. 2014, 472, 211-218. [CrossRef]

7. Zhu, B.; Fan, L.; Lund, P. Breakthrough fuel cell technology using ceria-based multi-functional nanocomposites. Appl. Energy 2013, 106, 163-175. [CrossRef]

8. Wang, X.; Ma, Y.; Zhu, B. State of the art ceria-carbonate composites (3C) electrolyte for advanced low temperature ceramic fuel cells (LTCFCs). Int. J. Hydrogen Energy 2012, 37, 19417-19425. [CrossRef]

9. Näfe, H. Cause of "Multi-Ionic Conduction" and "Ionic Conductivity Enhancement" in Carbonate-Based Composite Electrolytes. Electrochim. Acta 2017, 248, 250-257. [CrossRef]

10. Xiong, X.; Lei, X.; Wang, J.; Huang, K. Synergetic proton conduction in $\mathrm{BaZr}_{0.8} \mathrm{Y}_{0.2} \mathrm{O}_{3-\delta}-$ carbonate composite electrolyte for intermediate-temperature solid oxide fuel cells. Solid State Ion. 2015, 279, 66-71. [CrossRef]

11. Li, X.; Xu, N.; Zhang, L.; Huang, K. Combining proton conductor $\mathrm{BaZr}_{0.8} \mathrm{Y}_{0.2} \mathrm{O}_{3-\delta}$ with carbonate: Promoted densification and enhanced proton conductivity. Electrochem. Commun. 2011, 13, 694-697. [CrossRef]

12. Hei, Y.; Huang, J.; Wang, C.; Mao, Z. Novel doped barium cerate-carbonate composite electrolyte material for low temperature solid oxide fuel cells. Int. J. Hydrogen Energy 2014, 9, 14328-14333. [CrossRef]

13. Katahira, K.; Kohchi, Y.; Shimura, T.; Iwahara, H. Protonic conduction in Zr-substituted $\mathrm{BaCeO}_{3}$. Solid State Ion. 2000, 138, 91-98. [CrossRef]

14. Park, K.Y.; Seo, Y.; Kim, K.B.; Song, S.J.; Park, B.; Park, J. Enhanced proton conductivity of yttrium-doped barium zirconate with sinterability in protonic ceramic fuel cells. J. Alloys Compd. 2015, 639, 435-444. [CrossRef]

15. Khan, I.; Tiwari, P.; Basu, S. Development of melt infiltrated gadolinium doped ceria- carbonate composite electrolytes for intermediate temperature solid oxide fuel cells. Electrochim. Acta 2019, 294, 1-10. [CrossRef]

16. Benamira, M.; Ringuedé, A.; Hildebrandt, L.; Lagergren, C.; Vannier, R.N.; Cassir, M. Gadolinia-doped ceria mixed with alkali carbonates for SOFC applications: II-An electrochemical insight. Int. J. Hydrogen Energy 2012, 37, 19371-19379. [CrossRef]

17. Zhu, B.J. Functional ceria-salt-composite materials for advanced ITSOFC applications. Power Sources 2003, 114, 1-9. [CrossRef]

18. Zhu, B. Next generation fuel cell R\&D. Int. J. Energy Res. 2006, 30, 895-903. 